\begin{tabular}{r|ll} 
AL-ISHLAH & Volume & $: 18$ \\
Nomor & $: 1$ \\
Jurnal Pendidikan Islam & Tahun & $: 2020$ \\
\hline
\end{tabular}

\title{
Pengaruh Kedisiplinan Belajar Siswa Terhadap Prestasi Belajar pada Mata Pelajaran Pendidikan Agama Islam di SMPN 3 Pekalongan
}

\author{
Riyadlotussholikhah \\ Institut Agama Islam Negeri Pekalongan \\ email: riya.sholikhah@yahoo.com
}

\begin{abstract}
This researcher is a field research with a quantitative approach. the population in this study were all students in SMP N 3 Pekalongan with a total of 400 students. Seals were examined as many as 78 techniques of data collection with questionnaires, documentation, interview methods. While the data analysis technique is using normality test, linearity test, preliminary analysis, hypothesis testing, simple linear regression equation.

The results showed that: Learning achievement in Islamic education subjects in SMP N 3 Pekalongan included in the very good category. This is evidenced by the value of student learning outcomes that have an average of 83. The value is in the class interval located at (83-90), so that learning achievement is categorized very well. Research results indicate that the results for variable $X$ (student learning discipline) are obtained $t$ value $=$ 1.757 with a significance level of 0.083. Because tcount $1.757<t$ table 1.99 and the significance level of $0.083<0.05, \mathrm{HO}$ is accepted and $\mathrm{Ha}$ is rejected. Thus, this hypothesis is not accepted or in other words student learning discipline has no influence and is significant on learning achievement. Based on the $R$ Square adjust value of 0.028. This value indicates that the influence of student learning discipline variables on PAI learning
\end{abstract}


achievement is $2.6 \%$ and the remaining $97.4 \%$ is influenced by other variables outside the research model.

Keywords: Discipline, Achievement

\begin{abstract}
Abstrak
Peneliti ini merupakan penelitian lapangan dengan pendekatan kuantitatif. populasi dalam penelitian ini adalah seluruh siswa di SMP N 3 Pekalongan yang berjumlah 400 siswa. Sempel yang di teliti sebanyak 78 Teknik pengumpulan data dengan kuesioner, dokumentsi, metode wawancara. Sedangkan teknik analisis data dengan menggunakan uji normalitas, uji linearitas, analisis pendahuluan, uji hipotesis, persamaan regresi linear sederhana.

Hasil penelitian menunjukan bahwa : Prestasi belajar pada mata pelajaran pendidikan agama Islam di SMP N 3 Pekalongan termasuk dalam kategori sangat baik. Hal ini dibuktikan dengan nilai hasil belajar siswa yang memiliki rata-rata 83. Nilai tersebut berada dalam interval kelas terletak pada (83-90), sehingga prestasi belajar dikategorikan sangat baik.Hasil pelitian menjukan bahwa hasil untuk variabel $\mathrm{X}$ (kedisiplinan belajar siswa) diperoleh nilai $t_{\text {hitung }}=1,757$ dengan tingkat signifikansi 0,083 . Karena nilai thitung $1,757<$ nilai $t_{\text {tabel }} 1,99$ dan tingkat signifikansi 0,083 $<0,05$, maka Ho diterima dan Ha ditolak. Dengan demikian maka Hipotesis ini tidak diterima atau dengan kata lain kedisiplinan belajar siswa tidak memiliki pengaruh dan signifikan terhadap prestasi belajar. Berdasarkan nilai adjust $R$ Square sebesar 0,028. Nilai tersebut menunjukan bahwa pengaruh variabel kedisiplinan belajar siswa terhadap prestasi belajar PAI sebsesar 2,6\% san sisanya 97,4\% dipengaruhi oleh variabel lain diluar model penelitian ini.
\end{abstract}

Kata kunci : Disiplin, Prestasi

AL-ISHLAH: Jurnal Pendidikan Islam

Volume 18, Nomor 1, Juni 2020

P-ISSN : 2685-6581; E-ISSN : 1693-7449 


\section{PENDAHULUAN}

Disiplin adalah sesuatu yang berkenaan dengan pengendaliandiri seseorang terhadap bentuk-bentuk aturan. Peraturan dimaksud dapat ditetapkan oleh orang yang bersangkutan maupun berasal dari luar. ${ }^{1}$ Disiplin dalam pendidikan yaitu titik pusat pendidikan, maka pendidikan tidak akan berjalan dengan baik tanpa adanya suatu disiplin dari masing-masing komponen, timbulnya sikap disiplin pada diri seseorang tidak dapat tumbuh tanpa adanya intervensi dan itu pun dilakukan secara bertahap. $^{2}$

Peraturan yang diterapkan di SMP N 3 Pekalongan hampir sama dengan sekolah negeri yang lain seperti: (1) seragam, setiap hari senin dan selasa memakai seragam osis, rabu-kamis memakai seragam baik, jum'at sabtu memakai seragam pramuka lengkap. (2) rambut tidak panjang bagi laki-laki (3) datang pada pukul 07:00 (4) dilarang mengotori dinding atau meja (5) wajib untuk menghormati kepala sekolah,guru dan para staf. Dengan adanya peraturan di harapkan dapat menciptakan kedisiplinan di sekolah. $^{3}$

Departemen pendidikan dan kebudayaan dalam surat keputusan mentri. tata tertib itu digunakan oleh seluruh sekolah, baik negri maupun swasta. tata tertib ini biasanya di pasang di setiap ruangan tata tertib ini begitu lengkap, yang mengatur dari tata tertib untuk murid sampai dengan tata tertib untuk warga sekolah, mulai dari kehadiran siswa di sekolah sampai dengan kegiatan diruang perpustakaan atau di ruang laboratorium. Sekolah dapat membuat tata tertib sendiri untuk menyesuaikan dengan kondisi dan kebutuhan sekolah.Beberapa tata tertib yang harus dibuat oleh

\footnotetext{
${ }^{1}$ Suharsimi Arikunto, Manajemen Pengajaran Secara Manusia (Jakarta: PT Rineka Cipta,1993), hlm. 114.

${ }^{2}$ Rudolf Dreikurs dan Pearl Cassel, Disiplin tanpa hukuman (Bandung: CV Remaja Rosdakarya, 2006), hlm. 6.

${ }^{3}$ Dokumentasi SMP N 3 Pekalongan pada tanggal 9 November 2018
}

\section{AL-ISHLAH: Jurnal Pendidikan Islam}


sekolah antara lain adalah (1) taat tertib perpustakaan sekolah, (2) tata tertib kantin sekolah, (3) tata tertib musola,(4) laboratorium bahasa, (5) taat tertib laboratorium biologi, kimia,dan fisika, (6) tata tertib lapangan olah raga (7) tata tertib kelas, dan sebagainya. ${ }^{4}$

Penerapan disiplin di setiap sekolah tidaklah sama, semua tergantung dari kebijaksanaan dan tujuan yang ingin dicapai oleh masing-masing sekolah tersebut. Pelaksaan disiplin yang diterapkan di sekolah ini bertujuan untuk mendidik dan melatih pesertadidiknya menjadi manusia indonesia memiliki keahlian dibidangnya agar mampu dan siap handal untuk bekerja secara profesional. Selain itu sekolah juga bertujuan agar para peserta didik di sekolah ini mampu menjadi pribadi yang tangguh yang sehat jasmani dan rohani serta berprilaku dan bersikap sesuai dengan aturan-aturan, nilai dan norma yang berlaku di masyarakat sehingga diharapkan mampu menghadapi segala macam tantangan yang mungkin dihadapi dalam kehidupannya. Jadi, pada prisipnya penerapan disiplin sekolah merupakan segala peraturan dan tata tertib harus ditaati dan dipatuhi oleh seluruh peserta didik. $^{5}$

Anak didik merupakan obyek penting dalam ilmu pendidikan. Begitu pentingnya faktor anak ini dalam pendidikan, sehingga ada aliran pendidikan yang menempatkan anak sebagai pusat dalam segala usaha pendidikan. ${ }^{6}$

Umat Islam pada umumnya menaruh perhatian secara serius terhadap kegiatan belajar, karena belajar adalah diperhatikan bahkan di wajibkan di dalam agama islam. Belajar merupakan sangat penting serta menilai sebagai kegiatan yang terpuji. ${ }^{7}$ hlm. 52-53.

${ }^{4}$ Suparlan, Membangun Sekolah Efektif (Yogyakarta: Hikayat Publishing, 2008),

${ }^{5}$ M.Sohib, Pola Asuh Orang Tua dalam Membantu Anak Mengembangkan Disiplin Diri (Jakarta: Rineka Cipta, 1998), hlm. 21.

${ }^{6}$ Nur Uhbiyati, Ilmu Pendidikan Islam (Bandung: CV Pustaka Setia, 1997), hlm. 104

${ }^{7}$ Nur Uhbiyati, Ilmu Pendidikan Islam... hlm. 105.

AL-ISHLAH: Jurnal Pendidikan Islam 
Belajar merupakan proses dasar dari perkembangan hidup manusia. Dengan belajar, manusia melakukan perunbahan-perubahan kualitatif individu sehingga tingkah lakunya berkembang. Semua aktifitas dari prestasi manusia tidak lain adalah hasil dari belajar. Belajar bukan hanya sekedar pengalaman, belajar adalah suatu proses, dan bukan suatu hasil. Karena itu belajar berlangsung secara aktif dan integratif dengan menggunakan berbagai bentuk perbuatan untuk mencapai suatu tujuan. ${ }^{8}$

Kemampuan berprestasi atau unjuk hasil belajar adalah suatu puncak proses belajar.siswa dapat menunjukan bahwa ia telah mampu memecahkan tugas belajar atau mentransfer hasil belajar, dari pengalaman sehari-hari di sekolah di ketahui bahwa ada beberapa siswa tidak mampu berprestasi dengan baik. Kemampuan berprestasi tersebut terpengaruh oleh proses penerimaan. pengaktifan, pra-pengelolan, pengolahan, penyimpanan serta pemanggilan untuk pembangkitan dan pengalaman. ${ }^{9}$

Pendidikan Islam adalah penataan individual dan sosial yang dapat menyebabkan seseorang tunduk taat pada Islam dan menerapkanya secara sempurna di dalam kehidupan individu dan masyarakat. psikologi pembelajaran PAI dapat dimaknai sebagai suatu ilmu pengetahuan yang mengkaji atau mempelajari tingkah laku individu (manusia), di dalam usaha mengubah tingkah lakunya yang dilandasi oleh nilai-nilai ajaran Islam dalam kehidupan pribadinya atau kehidupan kemasyarakatannya dan kehidupan dalam alam sekitar melalui proses kependidikan. ${ }^{10}$

Menurut pendapat Noeng Muhadjir dalam buku Ilmu pendidikan dan perubahan sosial suatu teori pendidikan, menjelaskan suatu kawasan studi dapat tampil dan menampilkan diri sebagai suatu disiplin ilmu, bila di penuhi setidaknya tiga syarat yaitu : memiliki objek studi yang eksplisit dari 104-105.

${ }^{8}$ Wasty Soemanto, Psikologi Pendidikan (Jakarta: PT Rineka Cipta, 1998), hlm.

${ }^{9}$ Dimyati dan Mudjiono, Belajar dan Pembelajaran (Jakarta: PT Rineka Cipta, 1998), hal. 243.

${ }^{10}$ Tohirin, Psikologi Pembelajaran Pendidikan Agama Islam Berbasis Integrasi dan Kompetensi (Jakarta:PT Raja Grafindo Persada, 2005), hlm. 9-10.

\section{AL-ISHLAH: Jurnal Pendidikan Islam}


disiplin lain, memiliki struktur atau sitematika yang juga eksplinsit dari disiplin lain dan memiliki metodologi pengembangan, oleh karena itu sifat ilmu pendidikan menekankan pada penerapan empirik, ilmu pendidikan sebagaimana juga ilmu-ilmu empirik lainya. ${ }^{11}$

Di SMP N 3 Pekalongan terdapat banyak kebijakan-kebijakan yang dilakukan oleh kepala sekolah terhadap warga sekolah terutama untuk siswanya sehingga dinamakan dengan peraturan sekolah. Adapun berbagai macam peraturan yang dikeluarkan itu dengan maksut untuk meningkatkan kedisiplinan siswa dalam belajar mengajar dan dalam bidang pendidikan khususnya pada bidang Pendidikan Agama Islam yang mengajarkan berbagai macam pengetahuan keislaman seperti Al-Qur'an. Akhlak, fiqih yang dapat diamalkan dalam kehidupan sehari-hari seperti yang diajarkan oleh guru Pendidikan Agama Islam di setiap awal pembelajaran selalu melakukan pembiasan tadarus Al-Qur'an dan akhir pembelajaran siswa dibiasakan melakukan sholat dhuha dan yang selalu melakukan kebiasan itu mempengaruhi prestasi belajar dan rata-rata mendapat nilai di atas KKM (Kriteria Ketuntasan Minimal). ${ }^{12}$

\section{METODE PENELITIAN}

a. Jenis penelitian

Jenis penelitian yang digunakan dalam penelitian ini adalah penelitian lapangan yaitu jenis penelitian yang bertujuan untuk memecahkan masalah dengan menggunakan bantuan data yang ada di lapangan. Yang bertujuan memecahkan masalah-masalah yang ada dalam kehidupan seharihari. $^{13}$ peneliti menggunakan jenis penelitian lapangan karena ingin

${ }^{11}$ Noeng Muhadjir , Ilmu pendidikan dan perubahan sosial suatu teori pendidikan (Yogyakarta: Rake Sarasin, 1993), hlm. 17.

${ }^{12}$ Harmini, Guru Mata Pelajaran Pendidikan Agama Islam, wawancara pribadi, Pekalongan 16 juli 2018.

${ }^{13}$ Kartini Kartono, Pengantar Metodologi Reseach sosial (Bandung: Alimni,2003), hlm. 27.

AL-ISHLAH: Jurnal Pendidikan Islam

Volume 18, Nomor 1, Juni 2020

P-ISSN : 2685-6581; E-ISSN : 1693-7449 
menggali berbagai data dan fakta yang ada di lapangan yang kemudian akan dianalisis menggunakan statistik. Adapun tempat penelitiannya adalah SMP N 3 Pekalongan.

b. Pedekatan penelitian

Dalam penelitian ini penulis menggunakan pendekatan kuantitatif. Penlitian kuantitatif adalah penelitian yang berupa angka-angka dan analis statistik. ${ }^{14}$ dalam pendekatan kuantitatif ini data digunakan untuk mengatahui pengaruh kedisiplinan belajar siswa terhadap prestasi belajar pendidikan agama Islam di SMP N 3 Pekalongan.

c. Analisis Uji Hipotesis

Teknik analisis data merupakan cara yang di tempuh dalam menilai,mengevakuasi data-data yang telah di kumpulkan. adapun analisis data yang di gunakan penelitian ini adalah analisis regresi sederhana dengan langakah-langkah sebagai berikut:

1) Bentuk umum persamaan linear sederhana yang menunjukan hubungan antara dua variabel, yaitu variabel $\mathrm{X}$ dan $\mathrm{Y}$ adalah: $\hat{\mathrm{Y}}=\mathrm{a}+\mathrm{bX}$

2) Dalam mencari persamaan regresi, terlebih dahulu mencari nilai a dan $b$ dengan rumus:

3) $b=\frac{\mathrm{n} \sum x y-\left(\sum x\right)\left(\sum y\right)}{\mathrm{n}\left(\sum x^{2}\right)-\left(\sum x\right)^{2}}$ $\mathrm{A}=\hat{\mathrm{Y}}-\mathrm{b}$

4) Menghitung kesalahan standar estimasi

$$
\text { Se }=\sqrt{\frac{\sum Y^{2}-\mathrm{a} \sum X Y-b \sum X Y}{n-2}}
$$

5) Menentukan nilai $t_{\text {test }}$

${ }^{14}$ Sugiyono, Metode Penelitian Pendidikan (Bandung: Alfabeta, 2016), hlm.13.

$$
\begin{array}{ll}
\text { AL-ISHLAH: Jurnal Pendidikan Islam } & \text { Volume 18, Nomor 1, Juni } 2020 \\
\text { P-ISSN : 2685-6581; E-ISSN : 1693-7449 }
\end{array}
$$




$$
\begin{aligned}
& S b=\frac{\text { e }}{\sqrt{\sum X^{2}-\frac{(\Sigma) Y^{2}}{\mathrm{n}}}} \\
& \mathrm{t}=\frac{b-\beta}{S b}
\end{aligned}
$$

Keterangan:

Y : Variabel terikat (Dependent)

a : penduga bagi intersep $(\alpha)$

$\mathrm{b}$ : penduga bagi koefesien regresi $(\beta)$, dan $\alpha, \beta$ adalah paramenter yang nilainya tidakdiketahui sehingga diduga menggunakan statistik sampel.

$\mathrm{X}$ :variabel bebas (Independent)

$\mathrm{X}$ : nilai rata-rata $\mathrm{X}$

$\hat{\mathrm{Y}}$ : nilai rata-rata $\mathrm{y}$

Se : standar estimasi ${ }^{15}$

\section{d. Populasi dan sampel}

Populasi dalam penelitian ini adalah seluruh siswa yang berjumlah 400 siswa.danTeknik pengambilan sampel dalam penelitian ini adalah purposive sampling, yaitu teknik pengambilan sampel dengan pertimbangan tertentu. ${ }^{16}$ Dalam penelitian ini, peneliti memilih Setiap stratumnya terdiri dari kelas VII berjumlah 26 siswa, kelas VII berjumlah 26 siswa, dan IX berjumlah 26 siswa. sampel dalam penelitian ini adalah 78 sampel.

${ }^{15}$ Salafudin, Statistik Terapan untuk Penelitian Sosial (Pekalongan: STAIN Pekalongan Press, 2010), hlm. 147.

${ }^{16}$ Sugiyono, Metode Penelitian Kuantitatif, Kualitatif, dan $R \& D, \ldots$ hlm. 85.

\section{AL-ISHLAH: Jurnal Pendidikan Islam}




\section{PEMBAHASAN}

Berdasarkan data yang diperlukan untuk menjawab permasalahan itu, maka peneliti akan menggunakan analisis statistik dengan langkahlangkah sebagai berikut:

a. Uji Normalitas

Uji normalitas bertujuan untuk menguji apakah dalam model regresi, variabel pengganggu atau residual memiliki distribusi normal. Seperti diketahui bahwa uji t dan F mengasumsikan bahwa nilai residual mengikuti distribusi normal. Kalau asumi ini dilanggar maka uji statistik menjadi tidak valid untuk jumlah sampel kecil. ${ }^{17}$ Untuk mendeteksi apakah residual distrbusi normal atau tidak dengan menggunakan uji Kolmogorov-smirnov yang pengolahan datanya menggunakan aplikasi program SPSS versi 23 for windows.

b. Uji Linearitas

Uji linearitas digunakan untuk melihat apakah spesifikasi model yang digunakan sudah benar atau tidak. ${ }^{18}$ Untuk mendeteksi spesifikasi model yang digunakan sudah benar atau tidak dengan menggunakan analisis aplikasi program SPSS versi 23 for windows. Kaidah yang digunakan dalam menentukan sebaran linier atau tidaknya atau tidaknya adalah jika $(p>0,05)$ maka sebarannya adalah linier, jika $(\mathrm{p}<0,05)$ maka sebarannya tidak linier. c. Analisis Pendahuluan

Pada analisis pendahuluan dilakukan uji validitas dan reliabilitas dari variabel $\mathrm{X}_{1}, \mathrm{X}_{2}$ dan $\mathrm{Y}$ pada masing-masing item pertanyaan yang akan disebar pada responden dengan menggunakan penskoran, yaitu:

a) Untuk jawaban SL (selalu) diberi skor 4

b) Untuk jawaban $\mathrm{S}$ (sering) diberi skor 3

c) Untuk jawaban K (kadang-kadang) diberi skor 2

d) Untuk jawaban TP (tidak pernah) diberi skor 1

${ }^{17}$ Imam Ghozali, Aplikasi Analisis Multivariate dengan Program IBM SPSS 19 (Semarang: Badan Penerbit Universitas Diponegoro, 2011), hlm.160

${ }^{18}$ Imam Ghozali, Aplikasi Analisis Multivariate dengan Program IBM SPSS 19 (Semarang: Badan Penerbit Universitas Diponegoro, 2011),hlm.166.

\section{AL-ISHLAH: Jurnal Pendidikan Islam}




\section{d. Analisis Uji Hipotesis}

Teknik analisis data merupakan cara yang di tempuh dalam menilai,mengevakuasi data-data yang telah di kumpulkan. adapun analisis data yang di gunakan penelitian ini adalah analisis regresi sederhana dengan langakah-langkah sebagai berikut:

6) Bentuk umum persamaan linear sederhana yang menunjukan hubungan antara dua variabel, yaitu variabel $\mathrm{X}$ dan $\mathrm{Y}$ adalah: $\hat{\mathrm{Y}}=\mathrm{a}+\mathrm{bX}$

7) Dalam mencari persamaan regresi, terlebih dahulu mencari nilai a dan $b$ dengan rumus:

8) $b=\frac{\mathrm{n} \sum x y-\left(\sum x\right)\left(\sum y\right)}{\mathrm{n}\left(\sum x^{2}\right)-\left(\sum x\right)^{2}}$

$$
\mathrm{A}=\hat{\mathrm{Y}}-\mathrm{b}
$$

9) Menghitung kesalahan standar estimasi

$$
S e=\sqrt{\frac{\sum Y^{2}-\mathrm{a} \sum X Y-b \sum X Y}{n-2}}
$$

10) Menentukan nilai $t_{\text {test }}$

$$
\begin{aligned}
& S b=\frac{\mathrm{Se}}{\sqrt{\sum X^{2}-\frac{\left(\sum\right) Y^{2}}{\mathrm{n}}}} \\
& \mathrm{t}=\frac{b-\beta}{S b}
\end{aligned}
$$

Keterangan:

Y : Variabel terikat (Dependent)

a : penduga bagi intersep $(\alpha)$ 
b : penduga bagi koefesien regresi $(\beta)$, dan $\alpha, \beta$ adalah paramenter yang nilainya tidakdiketahui sehingga diduga menggunakan statistik sampel.

$\mathrm{X}$ :variabel bebas (Independent)

$X$ : nilai rata-rata $X$

$\hat{Y}$ : nilai rata-rata y

Se : standar estimasi ${ }^{19}$

11) Persamaan Regresi Linier Sederhana

Dalam melakukan analisis uji hipotesis ini peneliti akan menggunakan rumus persamaan regresi linier sederhana. Dalam hal ini penulis menggunakan analisis aplikasi program SPSS versi 23 for windows. Pada analisis regresi, hubungan antara variabel dependen (Y) dengan variabel independen (X) dinyatakan sebagai persamaan regresi yang merupakan persamaan estimasi linear, persamaan tersebut dinyatakan sebagai berikut: ${ }^{20}$

$$
\hat{\mathrm{Y}}=\mathrm{a}+\mathrm{bX}
$$

Dimana :

$\hat{\mathrm{Y}}=\mathrm{Y}$ hat $/ \mathrm{Y}$ topi adalah nilai estimasi $\mathrm{Y}$

$\mathrm{a}=$ intersep kurva estimasi konstanta

$\mathrm{b}=$ gradien / kemiringankurva estimasi disebut juga sebagai

koefisien regresi

$\mathrm{X}=$ nilai $\mathrm{C}$

\section{KESIMPULAN}

Berdasarkan penellitian dan analisis yang peneliti lakukan terhadap permasalahan yang di angkat maka peneliti dapat menyimpulkan sebagai berikut:

${ }^{19}$ Salafudin, Statistik Terapan untuk Penelitian Sosial (Pekalongan: STAIN Pekalongan Press, 2010), hlm. 147.

${ }^{20}$ Sudjana, Metode Statistika (Bandung: Tarsito, 2002), hlm.312.

\section{AL-ISHLAH: Jurnal Pendidikan Islam}


1. Kedisiplinan siswa di SMP N 3 Pekalongan termasuk dalam kategori cukup baik.hal ini dibuktikan dengan hasil angket tentang kedisiplinan siswa di SMP N 3 Pekalongan menunjukan berada pada interval 87-93 yang masuk dalam kategori kualifikasi cukup baik

2. Prestasi belajar pada mata pelajaran pendidikan agama Islam di SMP N 3 Pekalongan termasuk dalam kategori sangat baik. Hal ini dibuktikan dengan nilai hasil belajar siswa yang memiliki rata-rata 83. Nilai tersebut berada dalam interval kelas terletak pada (83-90), sehingga prestasi belajar pendidikan agama Islam di SMP N 3 Pekalogan dikategorikan sangat baik.

3. Hasil pelitian menjukan bahwa untuk kedisiplinan belajar siswa diperoleh nilai $t_{\text {hitung }}=1,757$ dengan signifikansi 0,083 . Karena nilai $t_{\text {hitung }} 1,757<$ nilai $t_{\text {tabel }} 1,99$ dan tingkat signifikansi $0,083<$ 0,05, Ho diterima dan $\mathrm{H}_{\mathrm{a}}$ ditolak. Dengan demikian maka Hipotesis ini tidak diterima atau dengan kata lain kedisiplinan belajar siswa tidak memiliki pengaruh signifikan terhadap prestasi belajar.Sedangkan berdasarkan nilai adjust $R$ Square sebesar 0,028. Nilai tersebut menunjukan bahwa pengaruh variabel kedisiplinan belajar siswa terhadap prestasi belajar Pendidikan Agama Islam sebsesar 2,6\% d an sisanya 97,4\% dipengaruhi oleh variabel lain diluar model penelitian ini.

\section{REFERENSI}

Arikunto, Suharsimi, 1993, Manajemen Pengajaran Secara Manusia ,Jakarta: PT Rineka Cipta

Arikunto, Suharsimi, 2010. Prosedur penelitian suatu pendekatan praktik, Jakarta: PT Rineke Cipta

Dimyati dan Mudjiono, 1998. Belajar dan Pembelajaran, Jakarta: PT Rineka Cipta, 1998.

\section{AL-ISHLAH: Jurnal Pendidikan Islam}


Dokumentasi SMP N 3 Pekalongan pada tanggal 9 November 2018 Dreikurs, Rudolf dan Pearl Cassel, 2006, Disiplin tanpa hukuman . Bandung: CV Remaja Rosdakarya

Faisal, Sanapiah, 1982. Metodologi Penelitian Pendidikan, Surabaya: Usaha Nasional

Ghozali, Imam, 2011. Aplikasi Analisis Multivariate dengan Program IBM SPSS 19 Semarang: Badan Penerbit Universitas Diponegoro Margono, S 1997, Metodologi Penelitian Pendidikan. Jakarta: Rineka Cipta. Muhadjir, Noeng 1993. Ilmu pendidikan dan perubahan sosial suatu teori pendidikan Yogyakarta: Rake Sarasin, 1993

Purwanto,2008. Metode Penelitian Kuantitatif Untuk Psikologi dan Pendidikan, Yogyakarta: Pustaka Pelajar

Salafudin, 2010. Statistik Terapan untuk Penelitian Sosial (Pekalongan: STAIN

Pekalongan Press.

Salafudin dan Nalim, 2014, Statistik Inferensial, Pekalongan: STAIN Press. Suparlan,2008. Membangun Sekolah Efektif , Yogyakarta: Hikayat Publishing

Sohib,M. 1998. Pola Asuh Orang Tua dalam Membantu Anak Mengembangkan Disiplin Diri, Jakarta: Rineka Cipta

Tohirin, 2005. Psikologi Pembelajaran Pendidikan Agama Islam Berbasis Integrasi dan Kompetensi, Jakarta : PT Raja Grafindo Persada Uhbiyati, Nur ,1997. Ilmu Pendidikan Islam, Bandung : CV Pustaka Setia Sugiyono,2016. Metode Penelitian Pendidikan ,Bandung: Alfabeta. Sudjana,2002. Metode Statistika, Bandung: Tarsito 